\title{
Editorial
}

\section{D\&O liability insurance: Crisis and opportunity}

In the last year directors and officers liability $(\mathrm{D} \& \mathrm{O})$ insurance premiums have fallen by 10 per cent as the result of excess capacity brought about by the entry into the market of the Class of 2001 - Bermuda-based insurers who entered the market in that year without legacies. Their entry was prompted by the dramatic rise in premiums after the series of scandals that came to light after the collapse of Enron, but the subsequent fall in premiums is driven by competition rather than a reduction in underlying risk, thus effectively reducing overall industry profitability. This brings into question the continued availability of D\&O insurance and the perceived health of the industry, which is the prerequisite for insurance to have any meaning. Indeed, the average settlement of claims continues to rise, and new areas of liability continue to develop, not the least of which is independent director's liability. What may be worse is that institutional investors are demanding personal liability for directors as well as officers, raising doubts about the very notion of $\mathrm{D} \& \mathrm{O}$ insurance.

This special issue of the journal focuses on issues of most concern to independent directors after the Enron and Worldcom settlements and includes an in-depth examination of the state and future of the D\&O industry, its legal environment and the potential for new products. The most important issue facing the industry is managing governance risk, the underlying risk of payouts of D\&O insurance. The paradox underlying insurance is that the better the coverage for directors and officers, the greater the moral hazard problem with less of incentive for those parties to exercise due diligence. But there is a way out of this dilemma. A recent issue of
Business Week in a cover story entitled 'Downsizing the CEO' reports that directors are often taking governance into their own hands with audit committee members telephoning auditors and making clear that the auditors are responsible to them and not to management.

Building on this trend, as well as the precedent settlements by directors at WorldCom and Enron, Michael Alles, Srikant Datar and John Friedland propose an entirely new conceptualisation of the nature and role of D\&O coverage: governance linked D\&O insurance. They systematically set out an approach to governance based on a set of standards and procedures which directors, especially those serving on the audit committee, should follow as a condition for higher D\&O coverage. The aim is to manage governance risk by providing directors with both the means and the motivation to reduce that risk, thus aligning their goals with those of insurers, who can, as a result, and unlike now, offer that extra coverage profitably. Douglas Clark and Cheryl Foung report on recent trends in litigation under the Private Securities Litigation Reform Acts (PSLRA). Anna Erickson White also considers recent trends in litigation in PSLRA cases and in derivative state law cases, as well as SEC enforcement actions and the potential impact on independent directors, suggesting means of reducing risk including increased due diligence before accepting a position, documenting the process and careful scrutiny of D\&O. William Redington examines best practice underwriting which goes substantially beyond Sarbanes-Oxley compliance. Dan Bailey surveys the legal landscape since the collapse of Enron in 2002, summarising 
class action mega-settlements, the dynamics of parallel proceedings and the growing trend towards personal liability for directors. Mike Early argues that the new litigation environment raises the likelihood that the trend created by Enron and Worldcom of demanding personal liability for directors is likely to continue. He examines increased government activity and regulation, the role of institutional investors, looks at ways of protecting the innocent director through D\&O policy wording and also considers means of evaluation of the financial condition of insurers, a subject not to be underestimated. Priya Huskins questions the merits of Side A insurance and whether the cost which is $70-80$ per cent of Side B or C is worth the additional protection it affords or whether Side B or C terms can be crafted to provide adequate coverage?

Professionals cannot predict the direction of premiums or the impact of future megasettlements. The recent actions brought in the insurance industry against Marsh, Aon, AIG and others are indicative of insurance marketplace in transition. That finite insurance per se has been the subject of scrutiny may expand the definition of accounting fraud. The conviction of Bernie Ebbers and the outcome of criminal prosecutions in Enron will keep accounting fraud in the spotlight. While business lobbying groups have asked for regulatory relief from Section 404 internal controls compliance standards, the public mood as evidenced by reports in Business Week, The Economist and the New York Times does not seem amenable to a backlash. Thus, the D\&O industry can only look forward to more of the same in the severity of class action suits and the success of state law claims.

Given this regulatory and litigation environment, independent directors would be well advised to make inquiries into the extent and term of their D\&O coverage, and begin demanding innovative new products such as governance-linked D\&O insurance.

Mr John Friedland Editor 